\section{BH3-only proteins that bind pro-survival Bcl-2 family members fail to induce apoptosis in the absence of Bax and Bak}

\author{
Wei-Xing Zong, ${ }^{1}$ Tullia Lindsten, ${ }^{1}$ \\ Andrea J. Ross, ${ }^{2}$ Grant R. MacGregor, ${ }^{3}$ \\ and Craig B. Thompson ${ }^{1,4}$
}

\begin{abstract}
${ }^{1}$ Departments of Medicine, Cancer Biology, and Pathology and Laboratory Medicine, Abramson Family Cancer Research Institute, University of Pennsylvania, Philadelphia, Pennsylvania 19104, USA; ${ }^{2}$ Graduate Program in Biochemistry, Cell and Developmental Biology, and ${ }^{3}$ Center for Molecular Medicine, Emory University School of Medicine, Atlanta, Georgia 30322, USA
\end{abstract}

The BH3-only proteins Bim and Bad bind to the antiapoptotic Bcl-2 proteins and induce apoptosis in wildtype cells and cells from either $\mathrm{bax}^{-/-}$or $\mathrm{bak}^{-/-}$animals. In contrast, constitutively active forms of Bim and Bad failed to induce apoptosis in $\mathrm{bax}^{-/-} \mathrm{bak}^{-/-}$cells. Expression of Bax restored susceptibility of the cells to Bim and Bad. In addition, Bax but not Bim or Bad sensitized the $\mathrm{bax}^{-/-} \mathrm{bak}^{-/-}$cells to a wide variety of cell death stimuli including UV irradiation, chemotherapeutic agents, and ER stress. These results suggest that neither activation of BH3-only proteins nor suppression of pro-survival Bcl-2 proteins is sufficient to kill cells in the absence of both Bax and Bak. Furthermore, whereas mouse embryo fibroblasts (MEF) expressing only Bax or Bak displayed resistance to transformation, $\mathrm{bax}^{-/-} \mathrm{bak}^{-/-} \mathrm{MEF}$ were nearly as prone to oncogenic transformation as $p 53^{-/-}$ MEF. Thus, the function of either Bax or Bak appears required to initiate most forms of apoptosis and to suppress oncogenic transformation.

Received March 26, 2001; revised version accepted April 27, 2001.

Bcl-2 family proteins play pivotal roles in controlling programmed cell death. Whereas some members prevent cell death, others exhibit a proapoptotic activity. Two major groups of Bcl-2 family proteins exist as follows: the pro-survival members including Bcl-2, Bcl- $\mathrm{x}_{\mathrm{L}}, \mathrm{Bfl}-1 /$ A1, Bcl-w, Mcl-1, Boo, NR-13, BHRF1, LMW5-HL, ORF16, KS-Bcl-2, E1B-19K, and Ced-9, and the proapoptotic members including Bax, Bak, and Bok (for review, see Adams and Cory 1998). Three-dimensional imaging suggests that both proapoptotic and antiapoptotic Bcl-2 family members share a common structure. Bcl-2 proteins have been shown to interact and to be regulated by another group of proteins that share at least one common

[Key Words: BH3-only; Bim; Bad; Bcl-2; Bax; Bak]

${ }^{4}$ Corresponding author.

E-MAIL drt@mail.med.upenn.edu; FAX (215) 746-5511.

Article and publication are at http://www.genesdev.org/cgi/doi/10.1101/ gad.897601. structural feature with Bcl-2 related proteins, an $\alpha$-helical structure termed $\mathrm{BH} 3$-domain. $\mathrm{BH} 3$-only members include Bad, Bim, Bid, Bik/Nbk, BNIP3, Blk, Hrk, Noxa, and EGL-1. Some BH3-only proteins selectively interact with antiapoptotic Bcl-2 family members, whereas others also interact with proapoptotic family members. All $\mathrm{BH} 3$ proteins discovered to date are proapoptotic (for review, see Huang and Strasser 2000).

$\mathrm{BH} 3$-only proteins have been proposed to be allosteric regulators of the Bcl-2 family of proteins, and serve as central effectors of apoptotic signaling pathways. For example, Bid is normally localized in the cytosol in an inactive form. The engagement of Fas ligand with Fas results in the activation of caspase 8 . Active caspase 8 in turn cleaves p22 Bid into the death-promoting p15 tBid, which is then targeted to the mitochondria and binds to either Bax or Bak and results in their oligomerization ( $\mathrm{Li}$ et al. 1998; Luo et al. 1998; Wei et al. 2000).

Unlike Bid, activation of Bim and Bad does not require caspase cleavage. Three isoforms of Bim exist due to alternative mRNA splicing: BimEL, BimL, and BimS (O'Connor et al. 1998). In healthy cells, BimEL and BimL are sequestered to the microtubule-associated dynein motor complex by binding to dynein light chain LC8, and are thereby unable to promote cell death. Certain death-inducing stimuli, such as serum withdrawal, induce the release of BimEL or BimL from the dynein motor complex. Once released, BimEL or BimL then translocates to mitochondria where they bind Bcl-2 and Bcl- $\mathrm{x}_{\mathrm{L}}$ and neutralizes their anti-apoptotic activity. BimS does not appear to interact with the microtubule complex, yet is still capable of binding to $\mathrm{Bcl}-2$ and $\mathrm{Bcl}-\mathrm{x}_{\mathrm{L}}$ (Puthalakath et al. 1999). Thus, BimS acts as a constitutive death inducer. Unlike tBid, Bim does not appear capable of binding the proapoptotic proteins Bax and Bak (O'Connor et al. 1998).

The activation of a third well-characterized BH3-only protein, Bad, is regulated by phosphorylation. Survival signals derived from growth factors lead to Bad phosphorylation and its retention in the cytosol in an inactive form bound to 14-3-3 scaffold proteins. Death-inducing stresses such as growth factor deprivation result in the dephosphorylation of $\mathrm{Bad}$ and its dissociation from 14-3-3. Bad then binds to and inhibits Bcl-2 and Bcl- $\mathrm{x}_{\mathrm{L}}$ and thereby promotes cell death. Re-exposure of the cells to growth factors inactivates Bad via phosphorylation mediated by PI(3)-kinase (Zha et al. 1996; Datta et al. 1997). In support of the role of serine phosphorylation in regulating Bad function, the mutation of serines 122, 136, 155 to alanine, converts Bad into a constitutive death-inducing molecule Bad(3A) (Datta et al. 1997; Virdee et al. 2000).

Bax/Bak double-deficient cells are defective in apoptosis (Lindsten et al. 2000). These cells are also defective in cell death initiated by tBid, demonstrating not only that tBid selectively interacts with Bax and Bak, but also that this interaction is required for the ability of tBid to initiate apoptosis (Wei et al. 2001). However, although these studies suggested that Bax and Bak can function as death effectors, they do not resolve whether antiapoptotic proteins such as Bcl-2 and Bcl- $\mathrm{x}_{\mathrm{L}}$ have an apoptotic function regulated by $\mathrm{BH} 3$-only proteins that is independent of Bax and Bak. To address this issue, we have used the constitutively active, death-promoting forms of Bim 
and Bad to neutralize the pro-survival Bcl-2 proteins. We report that Bim and Bad are incapable of inducing apoptosis in $b_{a x}^{-/-} b_{a k}^{-/-}$MEF. Thus, regulation of the proapoptotic function of Bax and Bak appears to be the point at which the function of $\mathrm{Bcl}-2$ related proteins is integrated.

\section{Results}

The BH3-only protein Bim does not induce apoptosis in $\mathrm{bax}^{-/-} \mathrm{bak}^{-/-}$cells

Bim proteins induce apoptosis by interacting with $\mathrm{Bcl}-\mathrm{x}_{\mathrm{L}}$ and $\mathrm{Bcl}-2$, and the short form BimS is constitutively proapoptotic (O'Connor et al. 1998). It remains uncertain whether Bim induces apoptosis by directly suppressing the pro-survival functions of $\mathrm{Bcl}-2$ and $\mathrm{Bcl}-\mathrm{x}_{\mathrm{L}}$, or by releasing the proapoptotic functions of Bax-like proteins from repression byBcl-2 and Bcl- $\mathrm{X}_{\mathrm{L}}$. To clarify this issue, we tested theability of BimS to induce apoptosis in $b_{a x}^{-/-} b^{-1-}$ MEF.

MEF obtained from wild-type, $b_{a x}^{-/-}, b_{a k}^{-/-}$, or $\mathrm{bax}^{-/-} \mathrm{bak}^{-/-}$backgrounds were infected with retrovirus expressing either green fluorescence protein (GFP), or both murine BimS and GFP from the same promoter using an internal ribosomal entry site (IRES). MEF with early passage number $(<6)$ were used to minimize the possibility of mutations acquired during culture. Whereas wild-type, $b a x^{-/-}$, and $b_{a k}{ }^{-/}$MEF infected with BimS showed massive cell death, $\mathrm{bax}^{-/-} \mathrm{bak}^{-/-}$cells were resistant to the proapoptotic action of BimS (Fig. 1A). Quantitation by 4,6-diamidino-2-phenylindole, dihydrochloride (DAPI) staining showed that $>70 \%$ of GFP-positive cells from wild-type and single deficient MEF were killed. Conversely, a marginal percentage of GFP-positive $\mathrm{bax}^{-/-} \mathrm{bak}^{-1-}$ cells were DAPI positive (Fig. 1B). Despite their resistance to cell death, $b_{a x}{ }^{-/-} b_{a k}{ }^{-/-} \mathrm{MEF}$ accumulated substantial amounts of BimS (Fig. 1C). The accumulated BimS was functional as judged by its ability to coprecipitate both endogenous Bcl-2 (Fig. 1D) and endogenous Bcl- $\mathrm{x}_{\mathrm{L}}$ (Fig. 1E). In addition, endogenous levels of Bcl-2 and Bcl- $\mathrm{x}_{\mathrm{L}}$ were not altered in the double knockout cells (Fig. 1F), indicating that the resistance of the double knockout MEF to cell death was not due to compensatory changes in the expression of these pro-survival Bcl-2 family members. Thus, whereas Bim is a potent cell death inducer in $\mathrm{MEF}$, its overexpression cannot induce apoptosis in the absence of both Bax and Bak.

The constitutively active BH3-only protein Bad fails to induce apoptosis in $\mathrm{bax}^{-/-} \mathrm{bak}^{-/-}$cells

$\mathrm{Bad}$ is another BH3-only protein that induces cell death by neutralizing the pro-survival Bcl-2 family members (Yang et al. 1995). We tested whether suppression of pro-survival Bcl-2 family members by $\mathrm{Bad}(3 \mathrm{~A})$, the constitutive death-inducing form of $\mathrm{Bad}$, could also lead to cell death in $b_{a x}^{-1-} b_{a k} k^{-1-}$ MEF. As predicted, $24 \mathrm{~h}$ after retroviral infection, significant numbers of $\mathrm{Bad}(3 \mathrm{~A})$ infected wild-type and Bax or Bak single knockout cells were dead, whereas the $b_{a x}{ }^{-/}$ $b_{a k}{ }^{-/}$cells survived (Fig. 2). Examination of the cells at later times failed to uncover any additional death in the $b_{a x}{ }^{-/} b_{a k}{ }^{-/}$cells although additional GFP-positive apoptotic cells were observed in the wild-type, bax $^{-/}$, and $b_{a k}{ }^{-1-}$ cells (data not shown).
A
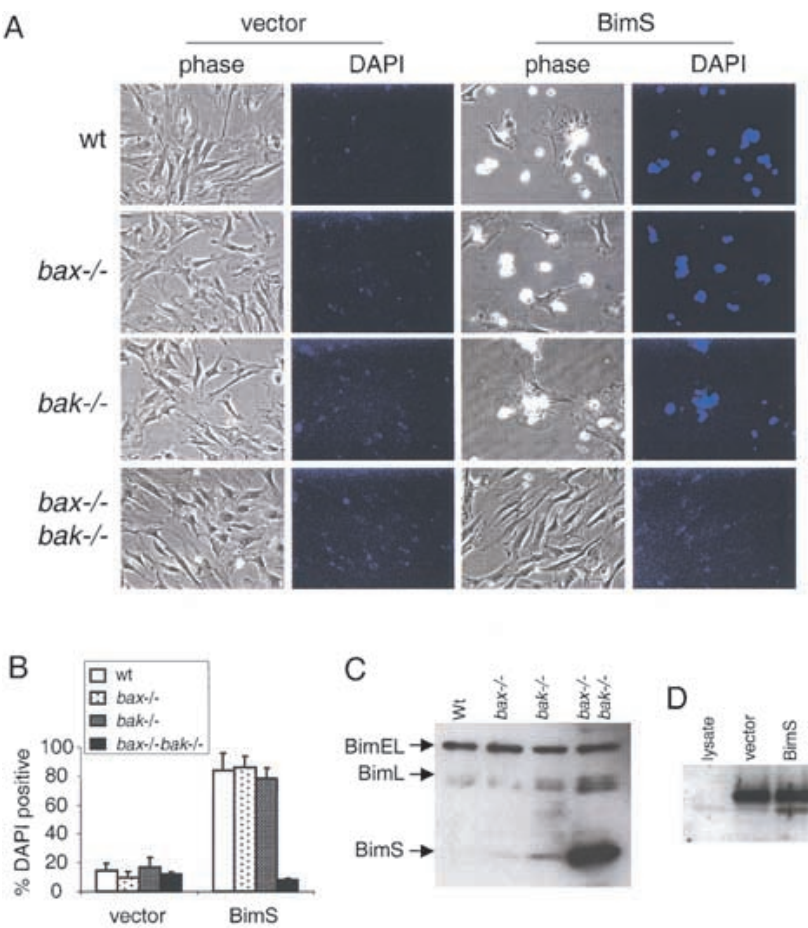

C
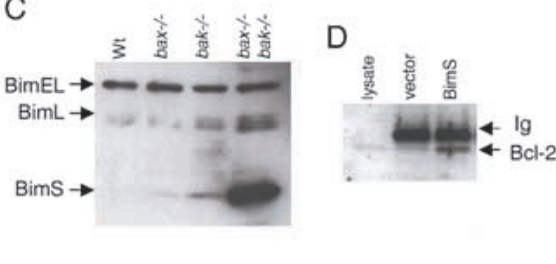

E
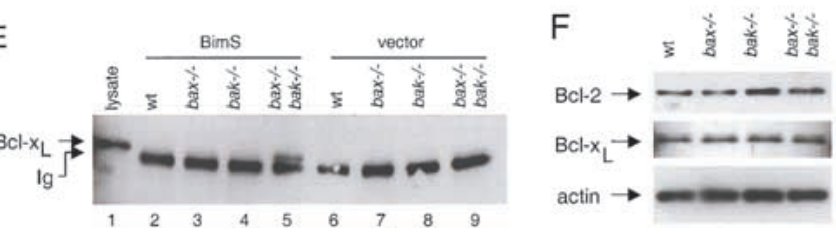

Figure 1. Bims does not induce apoptosis in $b a x^{-/-} b a k^{-/-}$MEF. (A) MEF of different genotypes were infected with pBabe-IRES-GFP (vector) or pBabeBimS-IRES-GFP (BimS). Twenty-four hours after infection, cells were stained with DAPI, and photographed under phase contrast or DAPI filter. (B) Cells from $A$ were collected and subjected to flow cytometric analysis (FACS). The percentage of dead cells was determined by the ratio of DAPIpositive cells to GFP-positive cells. Data shown is the average of three independent experiments. $(C)$ Western blot with anti-Bim of lysates obtained from MEF with different genotypes infected with BimS. Ectopically expressed BimS and endogenous BimEL and BimL are indicated. (D) BimS interacts with Bcl-2 in bax ${ }^{-1-} b_{a k}^{-/-}$cells. bax ${ }^{-/-} b a k^{-/-}$MEF infected with control vector or BimS were lysed. Immunoprecipitation and immunoblotting as described in Materials and Methods were performed with an antiBcl-2 antibody. A cell lysate from wild-type MEF was loaded as a control for Bcl-2 migration. The migration of immunoglobulin light chain (Ig) is also indicated. $(E)$ BimS interacts with Bcl- $\mathrm{x}_{\mathrm{L}}$ in $\mathrm{bax}^{-/-} \mathrm{bak}^{-/-}$cells. MEF infected with Bims or control vector were lysed. Immunoprecipitation and immunoblotting were performed as described in $D$ by use of an anti-Bcl- $\mathrm{x}_{\mathrm{L}}$ antibody. A cell lysate from wild-type MEF was loaded as a control for Bcl- $\mathrm{x}_{\mathrm{L}}$ migration. The migration of immunoglobulin light chain (Ig) is also indicated. $(F)$ Levels of Bcl-2 and Bcl- $\mathrm{x}_{\mathrm{L}}$ are not altered in $b_{a x^{-1-}} \mathrm{bak}^{-/-}$MEF. A Western blot of MEF lysates from different genotypes was probed with antibodies against $\mathrm{Bcl}-2, \mathrm{Bcl}-\mathrm{x}_{\mathrm{L}}$, and actin.

These findings show that the BH3-only proteins Bim and Bad could not kill cells in the absence of Bax and Bak, suggesting that it is the activation of Bax or Bak, rather than the suppression of pro-survival Bcl-2 members, that is required to effect apoptosis.

Bax restores susceptibility of $\mathrm{bax}^{-/-} \mathrm{bak}^{-/-}$MEF to Bim and Bad

To confirm that both Bim and Bad-mediated cell deaths are dependent on the function of a proapoptotic Bcl-2 


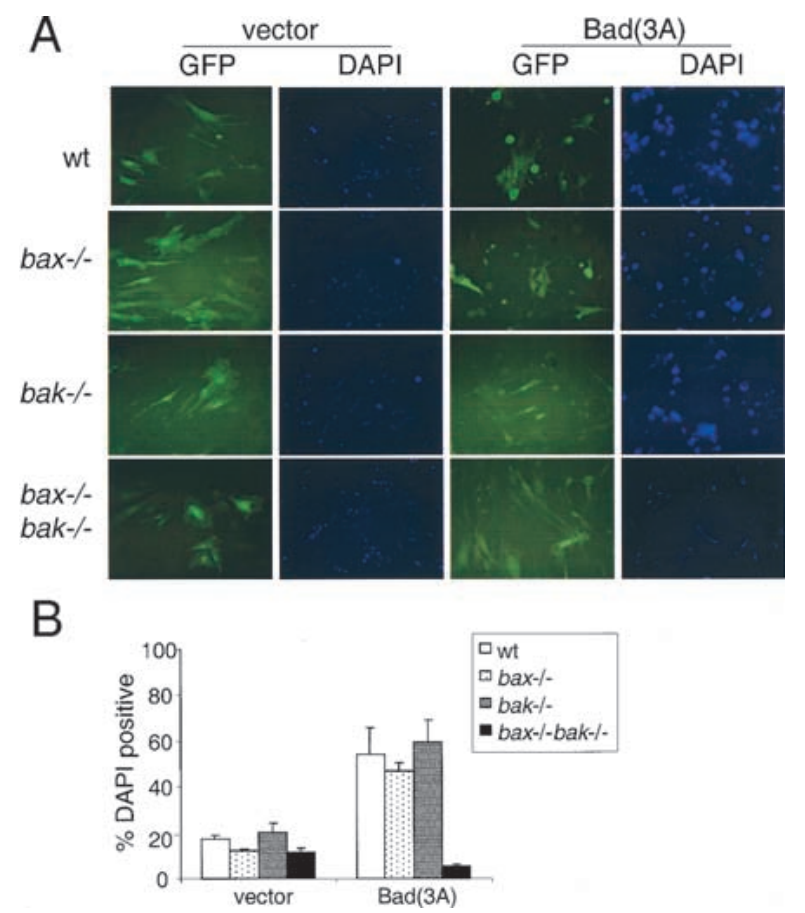

Figure 2. $\mathrm{BAD}(3 \mathrm{~A})$ does not induce apoptosis in $\mathrm{bax}^{-1-} \mathrm{bak}^{-/-} \mathrm{MEF}$. (A) MEF of different genotypes were infected with GFP (vector) or $\mathrm{BAD}(3 \mathrm{~A})$-IRES-GFP [Bad(3A)]. Twenty-four hours after infection, cells were stained with DAPI, and photographed by use of a FITC or DAPI filter. $(B)$ Cells from $A$ were collected and subjected to FACS analysis. The percentage of dead cells was determined by the ratio of DAPI-positive cells to GFP-positive cells. Data shown is the average of three independent experiments.

family member, Bax was re-introduced into $\mathrm{bax}^{-/-} \mathrm{bak}^{-/-}$ MEF together with BimS or Bad(3A) mutant. Coexpression of Bax and control GFP was not sufficient to kill $\mathrm{bax}^{-/-} \mathrm{bak}^{-/-}$cells. In contrast to the resistance to BimS or $\mathrm{Bad}(3 \mathrm{~A})$ expression, the $\mathrm{bax}^{-/-} \mathrm{bak}^{-/-}$cells were killed by BimS or Bad(3A) when Bax was co-expressed (Fig. $3 \mathrm{~A}, \mathrm{~B})$.

Bax but not Bim or Bad sensitizes bax ${ }^{-/-} \mathrm{bak}^{-/-}$cells to cell death stimuli

The above results demonstrated that either Bax or Bak is required for cell death mediated by Bim or Bad. These data suggest that the ability of Bim and Bad to bind prosurvival Bcl-2 proteins is insufficient to mediate cell death. However, it remained possible that Bim or Bad regulation of the function of the anti-apoptotic Bcl-2 proteins could be uncovered if $b_{a x}^{-1-} b_{a k}{ }^{-/-}$cells were subjected to exogenous apoptotic stimuli. To address this issue, $\mathrm{BimS}, \mathrm{Bad}(3 \mathrm{~A})$, or Bax was expressed in $\mathrm{bax}^{-/-}$ $b_{a k}{ }^{-1-} \mathrm{MEF}$, and the cells were then challenged with a spectrum of cell death-inducing stimuli including DNAdamaging agents, chemotherapeutic agents, and ER stress stimuli. Neither BimS nor Bad(3A) could sensitize the $b_{a x}^{-/-} b^{-1-}$ cells to these treatments in the absence of Bax and Bak (Fig. 3C). In sharp contrast, expression of Bax in $b_{a x}^{-/-} b_{a k}^{-/-}$cells restored the susceptibility of these cells to UV, etoposide, staurosporine, or brefeldin A (Fig. 3C). Furthermore, cells from mice having a single functional allele of either Bax or Bak had a pattern of cell death susceptibility to these agonists that was comparable with that of cells from wild-type mice /data not shown).

\section{Absence of Bax and Bak promotes oncogenic transformation}

It has been shown that Bax may contribute to p53-dependent suppression of oncogenic transformation (McCurrach et al. 1997) and the cell death induced by certain chemotherapeutic agents (Zhang et al. 2000). However, loss of bax results in only partially increased oncogenic transformation as compared with the loss of p53 (McCurrach et al. 1997). This has been argued to result from the ability of $\mathrm{BH} 3$-only proteins to promote apoptosis by directly inhibiting the antiapoptotic function of the prosurvival Bcl-2 family members (Huang and Strasser 2000). Recently, p53 has been shown to directly induce two proapoptotic BH3 containing proteins Noxa /Oda et al. 2000) and Puma (Nakano and Vousden 2001; Yu et al. 2001). In addition, Bim has been reported to be the apoptotic mediator of cell death in response to cytoskeleton disruption (Puthalakath et al. 1999), whereas Bad has been reported to mediate growth factor withdrawal-induced death. However, our findings suggest that either Bax or Bak is required to induce cell death in response to loss of attachment (anoikis) or serum deprivation (Fig. 4A). Both growth factor and anchorage independence have been associated with tumor development. This suggests that Bax and Bak might also share a redundant function that suppresses tumorigenicity through the independent ability of either of these proteins to initiate apoptosis in response to oncogenic transformation. To address this issue, we performed a soft agar focus-formation assay using primary MEF of different genotypes (wild-type, $\mathrm{bax}^{--}$, , $\mathrm{bak}^{-/-}, \mathrm{bax}^{-/-} \mathrm{bak}^{-/-}$, and $\mathrm{p} 53^{-/-}$). As anticipated, oncoprotein Ras and the adenovirus-5 E1A induced focus formation when p53 was inactivated (Fig. 4B,C; p53 $3^{-/-}$panels). Both bax ${ }^{-/-}$and bak $^{-/-}$single knockout cells produced a modest number of foci that was significantly less than that obtained from $p 53^{-/-}$ cells. Significantly, $b_{a x}^{-/-} b a k^{-/}$MEF transformed with Ras and E1A developed comparable numbers of foci, with that observed following transformation of $p 53^{-/-}$ MEF (Fig. 4B, C,D).

\section{Discussion}

The pro-survival Bcl-2 proteins such as $\mathrm{Bcl}-2 / \mathrm{Bcl}-\mathrm{x}_{\mathrm{L}}$ block apoptosis, whereas the Bax-like proteins Bax/Bak induce apoptosis. However, because these two groups of proteins antagonize each other's functions, it has been difficult to determine which molecules are the primary effectors of cell survival/death. Using $b_{a x}^{-/-} b^{-1 k^{-/}}$genetic background, we were able to address this issue in fibroblasts by manipulating the level of the pro-survival Bcl-2 proteins using the BH3-only agonists. We showed that neutralizing pro-survival Bcl-2 family members by the $\mathrm{BH} 3$-only proteins Bim and Bad was not sufficient to induce apoptosis in the absence of Bax and Bak. Introducing Bax back into the $b a x^{-/-} b_{a k}{ }^{-1-}$ background enabled Bim or Bad to kill these cells. Moreover, enforced expression of Bax, but not Bim or Bad, sensitized the $\mathrm{bax}^{-/-} \mathrm{bak}^{-/-}$MEF to physiological death stimuli. These 
Zong et al.

A

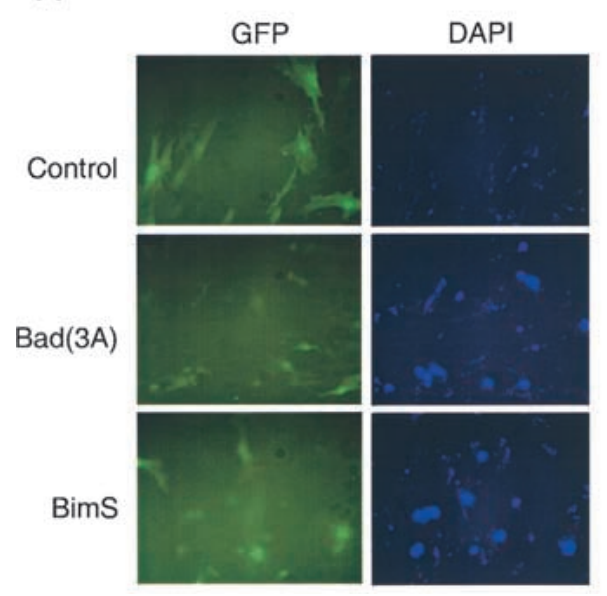

B

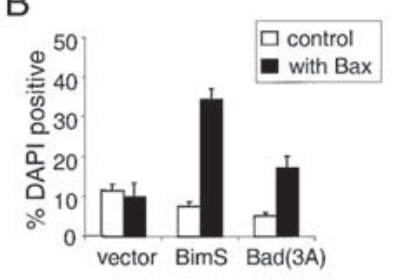

C

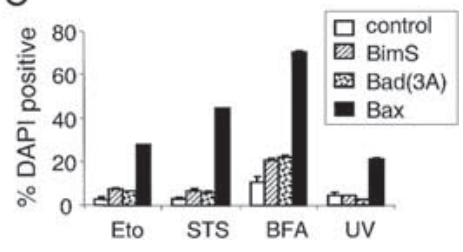

Figure 3. Bax restores the susceptibility of $b a x^{-/-} b a k^{-/-}$MEF to undergo apoptosis. $(A)$ Bax restores apoptosis sensitivity to $\mathrm{BimS}$ and $\mathrm{Bad}(3 \mathrm{~A})$. $\mathrm{bax}^{-1-} \mathrm{bak}^{-/-} \mathrm{MEF}$ were infected with Bax-IRES-GFP together with control (GFP), Bad(3A)-IRES-GFP, or BimS-IRES-GFP. Twenty-four hours after infection, cells were stained with DAPI and photographed by use of a FITC or DAPI filter. (B) bax ${ }^{-1-} b_{a k} k^{-/}$MEF were infected with BimS or Bad(3A) together with control or Bax vectors. The percentage of dead cells was determined $24 \mathrm{~h}$ later by the number of DAPI-positive cells over that of the GFP-positive cells. $(C)$ Bax, but not Bim or $\mathrm{Bad}$, sensitizes $b a x^{-1-} b a k^{-1-}$ cells to different death-inducing agents. $b a x^{-1-} b a k^{-1-}$ MEF were infected with control (GFP), BimS-IRES-GFP, Bad(3A)-IRES-GFP, or Bax-IRES-GFP. Twenty-four hours later, cells were treated with etoposide (Eto, $100 \mu \mathrm{M})$, staurosporine (STS, $4 \mu \mathrm{M})$, brefeldin A (BFA, $10 \mu \mathrm{g} / \mathrm{mL})$, or UV-irradiation $\left(200 \mathrm{~J} / \mathrm{m}^{2}\right)$. Cell death was determined $24 \mathrm{~h}$ later by the number of DAPI-positive cells over that of GFP-positive cells.

findings suggest that the proapoptotic proteins Bax and Bak are the effectors that execute cell death, and the antiapoptotic proteins $\mathrm{Bcl}-\mathrm{x}_{\mathrm{L}}$ and $\mathrm{Bcl}-2$ function to antagonize the Bax-like proteins. Whereas Bax and Bak appear to be the only proapoptotic Bcl-2 proteins that act asdeath effectors in fibroblasts, other proapoptotic family members may also act as death effectors in other tissues. For example, the third well-characterized proapoptotic family member, Bok, has a more restricted expression pattern than Bax or Bak and is expressed primarily in reproductive tissues (Hsu et al. 1997a).

The data support a model in which the BH3-only proteins are activated in response to death-inducing stimuli, and function to neutralize pro-survival Bcl-2 proteins and free the Bax-like proteins to execute cell death (Fig. 5). According to this model, the default status of a cell in the absence of both pro- and anti-apoptotic Bcl-2 family members is survival. MEF cell death requires the effector function of either Bax or Bak. In a healthy cell, this effect is antagonized by pro-survival Bcl-2 proteins. The balance between these two groups can be disrupted by the $\mathrm{BH} 3$-only proteins. In response to

A
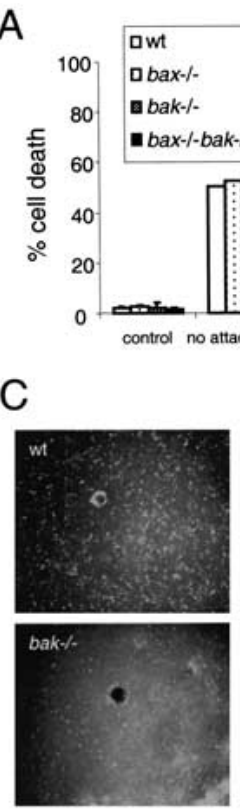
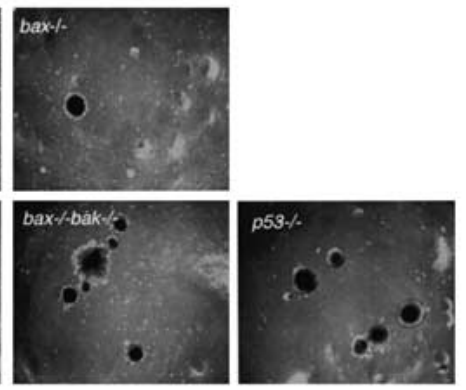

D

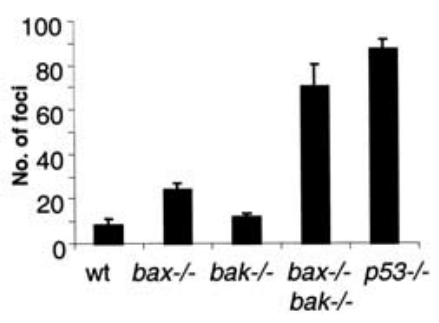

Figure 4. Loss of both Bax and Bak facilitates oncogenic transformation. (A) $\mathrm{bax}^{-/-} \mathrm{bak}^{-/-} \mathrm{MEF}$ are resistant to death induced by loss of attachment and serum deprivation. MEF of different genotypes were cultured in uncoated bacterial culture dishes or in the absence of FBS for $48 \mathrm{~h}$. The percentage of cell death was determined by PI-exclusion. $(B-D)$ MEF of different genotypes were infected with viral constructs expressing adenovirus-5 E1A and an activated ras oncogene, and cultured in soft agar. Two weeks after infection, plates were photographed and the number of foci scored. (B) Photographs of representative plates. $(C)$ Photographs of foci. $(D)$ Graph quantifying the number of foci from three experiments. 


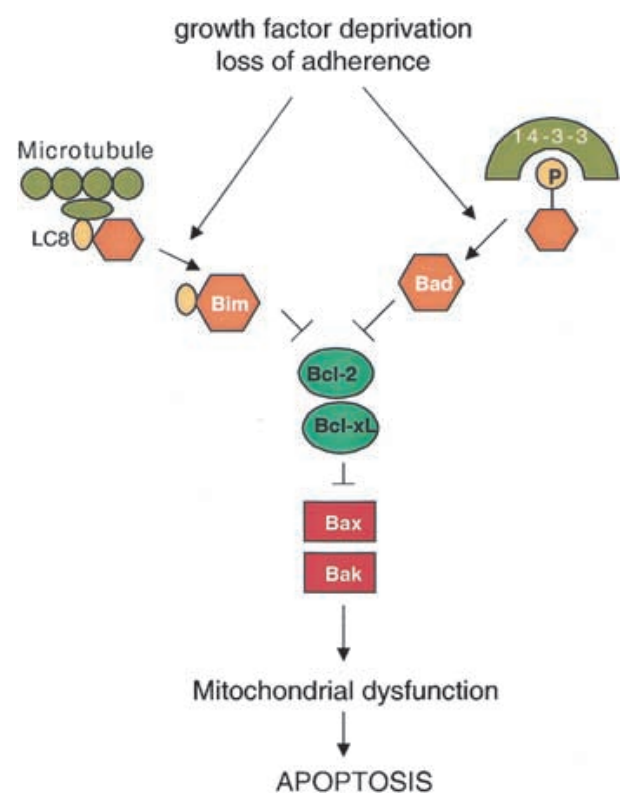

Figure 5. Model for regulation of apoptosis by Bcl-2 family members. Upon receiving cell death cues, the BH3-only proteins are activated. They activate proapoptotic Bax-like proteins Bax/Bak through neutralization of the anti-apoptotic Bcl-2 proteins.

It has been shown that Bax and Bak are activated by subcellular redistribution and/or conformational change after apoptosis is initiated. This cell death process can be blocked by overexpression of Bcl-2, Bcl- $\mathrm{x}_{\mathrm{L}}$, or E1B-19K (Hsu et al. 1997b; Perez and White 2000; Wei et al. 2000). Addition of recombinant Bax or Bak to isolated mitochondria induces cytochrome c release and the loss of mitochondrial potential (Jurgensmeier et al. 1998; Narita et al. 1998). Although these studies suggested that Bax/ Bak were specific initiators of apoptosis, it remains possible from these studies that the Bax or Bak overexpression was functioning to block endogenous $\mathrm{Bcl}-2 / \mathrm{Bcl}-\mathrm{x}_{\mathrm{L}}$ activities. Our studies show that the Bax-like proteins are essential for apoptosis execution. The data also suggest that the pro-survival Bcl-2 family members are not required to keep cells alive in the absence of Bax or Bak. This shows directly that Bax-like proteins have an intrinsic activity that induces apoptosis, whereas Bcl-2/ Bcl- $\mathrm{x}_{\mathrm{L}}$ function primarily to antagonize the death-promoting activities of $\mathrm{Bax} / \mathrm{Bak}$. This is consistent with the findings that Bax mutants that fail to bind Bcl-2 can still act as death effectors (Zha and Reed 1997), and that either Bax or Bak is toxic in yeast, which do not appear to encode any Bcl-2 homologs (Hanada et al. 1995; Jurgensmeier et al. 1997). Bax mutants that do not translocate into mitochondria are no longer able to induce apoptosis (Nechushtan et al. 1999). In contrast, Bcl-2 mutants that lack the membrane-anchoring domain but retain the ability to bind Bax can still block cell death (Borner et al. 1994).

One important question concerning antiapoptotic Bcl-2 proteins is whether they have a function in addition to antagonizing Bax-like proteins. All death stimuli we have tested have been reported to be suppressed by overexpression of Bcl-2/Bcl- $\mathrm{x}_{\mathrm{L}}$. However, blocking Bcl-2/ $B c l-x_{L}$ function by use of $\mathrm{BimS}$ or $\mathrm{Bad}(3 \mathrm{~A})$ did not sensitize the cells to etoposide, staurosporine, brefeldin A, and UV-irradiation (Fig. $3 \mathrm{C}$ ). This suggests that the primary function of Bcl-2 and Bcl- $\mathrm{x}_{\mathrm{L}}$ is to suppress the pro- apoptotic function of Bax and Bak. Thymocytes from $\mathrm{bax}^{-/-} \mathrm{bak}^{-/-}$mice are susceptible to Fas-mediated cell death (Lindsten et al. 2000), demonstrating that not all forms of apoptosis are dependent on Bax/Bak function. Interestingly, overexpression of Bcl-2 also fails to protect thymocytes from Fas-induced death (Strasser et al. 1995). Thus, it appears that expression of endogenous Bcl-2 members does not provide any anti-apoptotic resistance beyond that observed in $b_{a x}^{-/-} b_{a k}^{-/-}$cells.

Deregulation of apoptosis plays an important role in tumorigenesis. The pro-survival Bcl-2 members can be oncogenic. The connection between the pro-survival Bcl-2 members and tumorigenesis has been found in both clinical cases and transgenic models (for review, see Evan and Littlewood 1998). To a lesser extent, Bax mutation has been implicated in human leukemias, gastrointestinal cancer, and colorectal cancer (Rampino et al. 1997; Zhang et al. 2000). Abrogation of Bak expression has been observed in skin cancer and gastric and colorectal cancers (Rosen et al. 1998; Jackson et al. 2000). Expression of Bax may be regulated by p53 in some cells (Miyashita and Reed 1995), although there is no consensus p53 binding site in the mouse bax gene. A previous study has found that loss of Bax could reduce apoptosis and induce tumorigenicity in a p53-dependent manner in MEF, although to a lesser extent than loss of p53 itself (McCurrach et al. 1997). Our finding that loss of both Bax and Bak resulted in a significant increase of transformation in comparison with the single deficiency of Bax, indicates that these proapoptotic proteins are capable of compensating for each other in preventing transformation. Thus, the apparent redundancy of Bax and Bak may have been selected as a safeguard against oncogenic transformation as well as to assure the effective elimination of damaged or excess cells.

\section{Materials and methods}

Retroviral constructs

Murine BimS cDNA was obtained by RT-PCR by use of oligos 5 '-AG GCAGGATCCTCGAGCTATGGCCAAGCAACCTTC-3' and 5'-AGGC AGAATTCGTCGACTCAATGCCTTCTCCATAC-3'. BAD(3A) mutant cDNA was a gift from Dr. Michael Greenberg (MIT, Cambridge, MA). cDNAs of BimS, Bad(3A), and Bax were cloned into retroviral expression vector pBabeMN-IRES-GFP. Retroviral expression vectors for control (LPC), E1A (LPC-12S), and Ras (pBabe-Ras) were gifts of Dr. Scott W. Lowe (Cold Spring Harbor, NY).

Cell culture

Murine embryonic fibroblasts were generated from wild type, $b a x^{-/-}$ $b a k^{-/-}, b_{a x}^{-/-}$bak $k^{-/-}$, or $p 53^{-/-}$embryos. MEF were cultured in Dulbecco's modified Eagle medium (DMEM) supplemented with $10 \%$ fetal bovine serum (FBS), 100 units $/ \mathrm{mL}$ of penicillin and $100 \mu \mathrm{g} / \mathrm{mL}$ of streptomycin.

\section{Retroviral infection}

Phoenix cells $\left(5 \times 10^{6}\right)$ were plated in a 10 -cm culture dish the day before transfection. Cells were transfected with retroviral vectors expressing GFP (control), GFP-IRES-BimS (BimS), GFP-IRES-Bad(3A) (Bad(3A), or GFP-IRES-Bax (Bax). Viral supernatants were collected during the 4896-h period post-transfection, and centrifuged at $2000 \mathrm{rpm}$ for $10 \mathrm{~min}$ to get rid of contaminating packaging cells. MEF were infected with the viral supernatant in the presence of $10 \mu \mathrm{g} / \mathrm{mL}$ of polybrene (Sigma).

\section{Death assays}

MEF were left untreated or treated with staurosporine (4 $\mu \mathrm{M}$, Sigma), UVirradiation (200 Joules $/ \mathrm{m}^{2}$, Stratalinker, Stratagene), etoposide (100 $\mu \mathrm{M}$, Clontech), or brefeldin A (10 $\mu \mathrm{g} / \mathrm{mL}$, Sigma) for $24 \mathrm{~h}$, or cultured in uncoated bacterial culture dishes or in the absence of FBS for $48 \mathrm{~h}$. A total of $1 \mu \mathrm{g} / \mathrm{mL}$ DAPI or propidium iodide was added to cell culture. Cells were observed and photographed with the Nikon Eclipse TE300 microscope, and subjected to flow cytometry to determine the number of DAPI-positive cells over that of GFP-positive cells. Cell death was also determined by PI-exclusion. 
Immunoprecipitation and immunoblotting

One-million MEF were infected with control or BimS. Forty-eight hours after infection, cells were lysed in $500 \mu \mathrm{L} 20 \mathrm{mM}$ Tris (pH7.4), $100 \mathrm{mM}$ $\mathrm{NaCl}, 1.5 \mathrm{mM} \mathrm{MgCl} 2,10 \%$ Glycerol, and $0.5 \% \mathrm{NP}-40$ in the presence of a protease inhibitor cocktail (Roche Inc.). The lysates were pre-cleared with Protein G sepharose for $30 \mathrm{~min}$ at $4^{\circ} \mathrm{C}$, incubated with a polyclonal anti-Bim antibody (M-20, Santa Cruz) for $2 \mathrm{~h}$, followed by Protein G agarose beads (Life Technologies) for $1 \mathrm{~h}$ at $4^{\circ} \mathrm{C}$. The proteins were washed in the lysis buffer three times, and loaded on pre-cast SDS-PAGE gel (Novex). For immunoblotting, $20 \mu \mathrm{g}$ of protein was loaded on pre-cast gels in some experiments. Immunoblotting was performed by use of polyclonal antibodies against Bim (BD-Pharmingen), Bcl- $\mathrm{x}_{\mathrm{L}}$ (13.6), Bcl-2 (BDPharmingen), and actin (Santa Cruz).

Soft agar transformation assay

MEF with different genotypes (wild type, $\mathrm{bax}^{-/-}, \mathrm{bak}^{-/-}, \mathrm{bax}^{-/-} \mathrm{bak} \mathrm{k}^{-/-}$, or $p 53^{-/-}$) were infected with GFP or E1A together with Ras retrovirus. Twenty-four hours later, the infection efficiency was determined by the number of GFP-positive MEF present, as analyzed by FACS. Equal amounts of infected cells were plated in soft agar. Transformed foci were scored $14 \mathrm{~d}$ later, and photographed.

\section{Acknowledgments}

We thank Drs. Scott W. Lowe, Michael E. Greenberg, Aviva M. Tolkovsky, and Gary P. Nolan for providing reagents and members of the Thompson laboratory for helpful discussions. This work was supported by grants from the National Institutes of Health. W.X.Z. is a recipient of the Cancer Research Institute (CRI) Postdoctoral Fellowship.

The publication costs of this article were defrayed in part by payment of page charges. This article must therefore be hereby marked "advertisement" in accordance with 18 USC section 1734 solely to indicate this fact.

\section{References}

Adams, J.M. and Cory, S. 1998. The Bcl-2 protein family: Arbiters of cell survival. Science 281: 1322-1326.

Borner, C., Martinou, I., Mattmann, C., Irmler, M., Schaerer, E., Martinou, J.C., and Tschopp, J. 1994. The protein bcl-2 alpha does not require membrane attachment, but two conserved domains to suppress apoptosis. J. Cell. Biol. 126: 1059-1068.

Datta, S.R., Dudek, H., Tao, X., Masters, S., Fu, H., Gotoh, Y., and Greenberg, M.E. 1997. Akt phosphorylation of BAD couples survival signals to the cell- intrinsic death machinery. Cell 91: 231-241.

Evan, G. and Littlewood, T. 1998. A matter of life and cell death. Science 281: $1317-1322$.

Hanada, M., Aime-Sempe, C., Sato, T., and Reed, J.C. 1995. Structurefunction analysis of Bcl-2 protein. Identification of conserved domains important for homodimerization with Bcl-2 and heterodimerization with Bax. J. Biol. Chem. 270: 11962-11969.

Hsu, S.Y., Kaipia, A., McGee, E., Lomeli, M., and Hsueh, A.J. 1997a. Bok is a pro-apoptotic Bcl-2 protein with restricted expression in reproductive tissues and heterodimerizes with selective antiapoptotic Bcl-2 family members. Proc. Natl. Acad. Sci. 94: 12401-12406.

Hsu, Y.T., Wolter, K.G., and Youle, R.J. 1997b. Cytosol-to-membrane redistribution of Bax and $\mathrm{Bcl}-\mathrm{X}(\mathrm{L})$ during apoptosis. Proc. Nat1. Acad. Sci. 94: 3668-3672.

Huang, D.C. and Strasser, A. 2000. BH3-Only proteins-essential initiators of apoptotic cell death. Cell 103: 839-842.

Jackson, S., Harwood, C., Thomas, M., Banks, L., and Storey, A. 2000 Role of Bak in UV-induced apoptosis in skin cancer and abrogation by HPV E6 proteins. Genes \& Dev. 14: 3065-3073.

Jurgensmeier, J.M., Krajewski, S., Armstrong, R.C., Wilson, G.M., Oltersdorf, T., Fritz, L.C., Reed, J.C., and Ottilie, S. 1997. Bax- and Bak-induced cell death in the fission yeast Schizosaccharomyces pombe. Mol. Biol. Cell 8: 325-339.

Jurgensmeier, J.M., Xie, Z., Deveraux, Q., Ellerby, L., Bredesen, D., and Reed, J.C. 1998. Bax directly induces release of cytochrome c from isolated mitochondria. Proc. Nat1. Acad. Sci. 95: 4997-5002.

Li, H., Zhu, H., Xu, C.J., and Yuan, J. 1998. Cleavage of BID by caspase 8 mediates the mitochondrial damage in the Fas pathway of apoptosis Cell 94: 491-501.

Lindsten, T., Ross, A.J., King, A., Zong, W.X., Rathmell, J.C., Shiels, H.A., Ulrich, E., Waymire, K.G., Mahar, P., Frauwirth, K., et al. 2000
The combined functions of proapoptotic Bcl-2 family members bak and bax are essential for normal development of multiple tissues. Mol. Cell 6: 1389-1399.

Luo, X., Budihardio, I., Zou, H., Slaughter, C., and Wang, X. 1998. Bid, a $\mathrm{Bcl} 2$ interacting protein, mediates cytochrome c release from mitochondria in response to activation of cell surface death receptors. Cell 94: 481-490.

McCurrach, M.E., Connor, T.M., Knudson, C.M., Korsmeyer, S.J., and Lowe, S.W. 1997. bax-deficiency promotes drug resistance and oncogenic transformation by attenuating p53-dependent apoptosis. Proc. Natl. Acad. Sci. 94: 2345-2349.

Miyashita, T. and Reed, J.C. 1995. Tumor suppressor p53 is a direct transcriptional activator of the human bax gene. Cell 80: 293-299.

Nakano, K. and Vousden, K.H. 2001. PUMA, a novel proapoptotic gene, is induced by p53. Mol. Cell 7: 683-694.

Narita, M., Shimizu, S., Ito, T., Chittenden, T., Lutz, R.J., Matsuda, H., and Tsujimoto, Y. 1998. Bax interacts with the permeability transition pore to induce permeability transition and cytochrome c release in isolated mitochondria. Proc. Nat1. Acad. Sci. 95: 14681-14686.

Nechushtan, A., Smith, C.L., Hsu, Y.T., and Youle, R.J. 1999. Conformation of the Bax C-terminus regulates subcellular location and cell death. EMBO T. 18: 2330-2341.

O'Connor, L., Strasser, A., O'Reilly, L.A., Hausmann, G., Adams, J.M., Cory, S., and Huang, D.C. 1998. Bim: A novel member of the Bcl-2 family that promotes apoptosis. EMBO T. 17: 384-395.

Oda, E., Ohki, R., Murasawa, H., Nemoto, J., Shibue, T., Yamashita, T., Tokino, T., Taniguchi, T., and Tanaka, N. 2000. Noxa, a BH3-only member of the Bcl-2 family and candidate mediator of p53-induced apoptosis. Science 288: 1053-1058.

Perez, D. and White, E. 2000. TNF-a signals apoptosis through a Biddependent conformational change in Bax that is inhibited by E1B 19K. Mol. Cell 6: 53-63.

Puthalakath, H., Huang, D.C., O'Reilly, L.A., King, S.M., and Strasser, A. 1999. The proapoptotic activity of the Bcl-2 family member Bim is regulated by interaction with the dynein motor complex. Mol. Cell 3: 287-296

Rampino, N., Yamamoto, H., Ionov, Y., Li, Y., Sawai, H., Reed, J.C., and Perucho, M. 1997. Somatic frameshift mutations in the BAX gene in colon cancers of the microsatellite mutator phenotype. Science 275: 967-969.

Rosen, K., Rak, J., Jin, J., Kerbel, R.S., Newman, M.J., and Filmus, J. 1998. Downregulation of the pro-apoptotic protein Bak is required for the ras- induced transformation of intestinal epithelial cells. Curr. Biol. 8: $1331-1334$

Strasser, A., Harris, A.W., Huang, D.C., Krammer, P.H., and Cory, S. 1995. Bcl-2 and Fas/APO-1 regulate distinct pathways to lymphocyte apoptosis. EMBO J. 14: 6136-6147.

Virdee, K., Parone, P.A., and Tolkovsky, A.M. 2000. Phosphorylation of the pro-apoptotic protein BAD on serine 155, a novel site, contributes to cell survival. Curr. Biol. 10: 1151-1154.

Wei, M.C., Lindsten, T., Mootha, V.K., Weiler, S., Gross, A., Ashiya, M. Thompson, C.B., and Korsmeyer, S.J. 2000. tBID, a membrane-targeted death ligand, oligomerizes BAK to release cytochrome c. Genes \& Dev. 14: 2060-2071.

Wei, M.C., Zong, W.X., Cheng, E.H., Lindsten, T., Panoutsakopoulou, V., Ross, A.J., Roth, K.A., MacGregor, G.R., Thompson, C.B., and Korsmeyer, S.J. 2001. Proapoptotic Bax and Bak: A requisite gateway to mitochondrial dysfunction and death. Science 292: 727-730.

Yang, E., Zha, J., Jockel, J., Boise, L.H., Thompson, C.B., and Korsmeyer, S.J. 1995. Bad, a heterodimeric partner for Bcl-XL and Bcl-2, displaces Bax and promotes cell death. Cell 80: 285-291.

Yu, J., Zhang, L., Hwang, P.M., Kinzler, K.W., and Vogelstein, B. 2001 PUMA induces the rapid apoptosis of colorectal cancer cells. Mol. Cell 7: 673-682.

Zha, H. and Reed, J.C. 1997. Heterodimerization-independent functions of cell death regulatory proteins Bax and Bcl-2 in yeast and mammalian cells. J. Biol. Chem. 272: 31482-31488.

Zha, J., Harada, H., Yang, E., Jockel, J., and Korsmeyer, S.J. 1996. Serine phosphorylation of death agonist $\mathrm{BAD}$ in response to survival factor results in binding to 14-3-3 not BCL-X(L). Cell 87: 619-628.

Zhang, L., Yu, J., Park, B.H., Kinzler, K.W., and Vogelstein, B. 2000. Role of BAX in the apoptotic response to anticancer agents. Science $\mathbf{2 9 0}$ 989-992. 


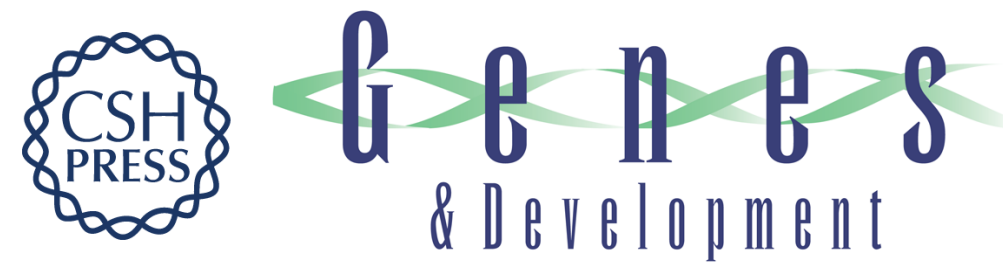

\section{BH3-only proteins that bind pro-survival Bcl-2 family members fail to induce apoptosis in the absence of Bax and Bak}

Wei-Xing Zong, Tullia Lindsten, Andrea J. Ross, et al.

Genes Dev. 2001, 15:

Access the most recent version at doi:10.1101/gad.897601

References This article cites 34 articles, 19 of which can be accessed free at: http://genesdev.cshlp.org/content/15/12/1481.full.html\#ref-list-1

License

Email Alerting

Receive free email alerts when new articles cite this article - sign up in the box at the top Service right corner of the article or click here.

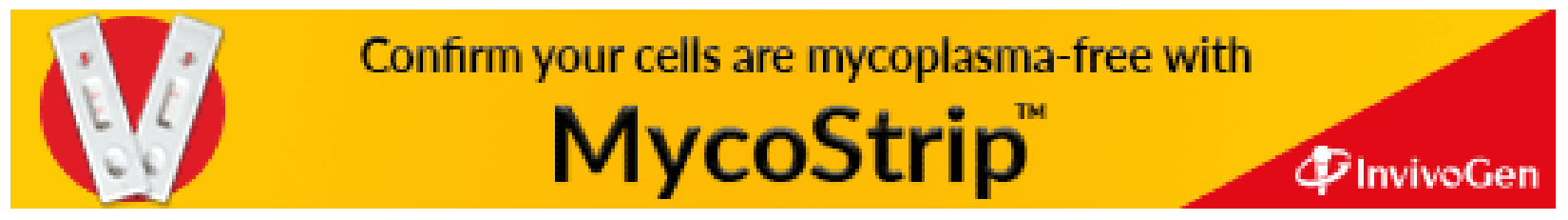

